\title{
Pemanfaatan Biomulsa Kacang Hias (Arachis pintoi) pada Budidaya Jagung Manis (Zea mays saccharata Sturt.) di Lahan Kering.
}

\author{
Utilization of Biomulch Arachis pintoi in Production of Sweet Corn \\ (Zea mays saccharata Strut.) at Upland Condition.
}

Fariidah Silmi ${ }^{1}$ dan M.A. Chozin ${ }^{1 *}$

Diterima 15 November 2013/Disetujui 14 Januari 2014

\begin{abstract}
ABSTARCT
The objective of the research was to determine the effect legume cover crop Arachis pintoi as biomulch on yield of sweet corn (Zea mays saccharata Strut.) as compared to Centrosema pubescens, Calopogonium mucunoides, no weeding, manual weeding, and plastic mulch. The research was conducted at Cikabayan Experimental Field, Bogor in February - September 2013. Experiment used randomized complete blocked design (RKLT), with single factor and three replications. The factor was difference type of mulch consisting of control (manual weeding), nature of vegetation (without weeding), plastic mulch, Arachis pintoi, Centrosema pubescens, and Calopogonium mucunoides. Biomulches influenced change of weeds compositions at research land. The treatment of $A$. pintoi biomulch suppressed growth of weeds lower than $\underline{C}$. pubescens and $\underline{C}$. mucunoides biomulch. The result revealed that different mulch had no significant effect on all of sweet corn variables except on cob length and cob circumference. A. pintoi, biomulch led was not significantly different compared to $\underline{C}$. pubescens, and $\underline{C}$. mucunoides. Plastic mulch increased sweet corn production component and production better than other treatments.
\end{abstract}

Keywords : biomulch, legume cover crop, weed, yield, yield component, sweet corn

\begin{abstract}
ABSTRAK
Penelitian ini dilakukan untuk mempelajari efek tanaman penutup tanah (Legume Cover Crop) Arachis pintoi sebagai biomulsa dan pengaruhnya terhadap produksi tanaman jagung manis (Zea mays saccharata Strut.) dibandingkan dengan Calopogonium mucunoides, Centrosema pubescens, tanpa penyiangan (vegetasi alami), penyiangan manual, dan mulsa plastik hitam perak. Penelitian dilaksanakan di Kebun Percobaan Cikabayan, Bogor pada bulan Februari-September 2013. Percobaan menggunakan rancangan kelompok lengkap teracak (RKLT) dengan satu faktor dan tiga ulangan. Faktor perlakuan tersebut adalah perbedaan jenis mulsa yang terdiri atas kontrol (dengan penyiangan manual), vegetasi alami (tanpa penyiangan), mulsa plastik hitam perak, Arachis pintoi, Centrosema pubescens, dan Calopogonium mucunoides. Penggunaan biomulsa mempengaruhi pergeseran jenis gulma yang tumbuh di lahan penelitian. Perlakuan biomulsa $A$. pintoi lebih rendah menekan pertumbuhan gulma dibandingkan dengan perlakuan biomulsa $C$. pubescens dan $C$. mucunoides. Hasil penelitian menunjukkan bahwa perbedaan jenis mulsa berpengaruh nyata terhadap semua peubah jagung manis yang diamati kecuali pada panjang tongkol dan lingkar tongkol. Hasil dan komponen hasil jagung manis tidak berbeda nyata antara perlakuan biomulsa A. pintoi, C. pubescens, dan C. mucunoides. Perlakuan mulsa plastik hitam perak berbeda nyata dibandingkan dengan perlakuan lainnya dalam meningkatkan hasil dan komponen hasil jagung manis.
\end{abstract}

Kata kunci: biomulsa, gulma, hasil, komponen hasil, jagung manis, RKLT, tanaman penutup tanah

${ }^{1}$ Departemen Agronomi dan Hortikultura, Fakultas Pertanian, Institut Pertanian Bogor

(Bogor Agricultural University), Jl. Meranti, Kampus IPB Darmaga, Bogor 16680, Indonesia

Telp. \& Faks.62-251-8629353*e-mail untuk korespondensi: ma_chozin@yahoo.com 


\section{PENDAHULUAN}

Jagung manis (Zea mays saccharata Sturt) merupakan jenis jagung yang memiliki rasa manis yang melebihi jagung biasa. Selain itu, masa produksinya yang relatif lebih singkat (genjah) membuat nilai ekonomis jagung manis relatif lebih tinggi di pasaran. Marliah et al. (2010) menyatakan bahwa jagung manis memiliki peranan yang cukup besar untuk meningkatkan produksi pangan dalam negeri, namun produktivitasnya masih rendah. Peng-gunaan benih dan teknologi serta budidaya yang kurang intensif di kalangan petani menyebabkan rendahnya hasil jagung manis (Rahayu, 2011).

Usaha peningkatan produksi jagung manis dapat dilakukan dengan meningkatkan produktivitas atau yang sering dikenal dengan istilah intensifikasi (Marliah, 2010). Mayadewi (2007) menambahkan pengembangan jagung manis secara intensif hanya dapat dilakukan oleh petani yang memiliki modal besar. Selain itu, masalah yang sering dihadapi petani adalah adanya kelangkaan pupuk yang mengakibatkan mahalnya harga pupuk di pasaran. Kebutuhan akan unsur hara yang dapat diperoleh dari pemberian pupuk serta interaksi tanaman dengan lingkungan tempat tumbuh akan sangat berpengaruh terhadap pertumbuhan vegetatif dan produksi tanaman jagung manis. Menurut Sintia (2011) faktor tersebut merupakan faktor penting yang dapat menghambat atau mendorong pertumbuhan serta produksi tanaman, sehingga pengaturan keadaan lingkungan perlu diupayakan.

Pemberian mulsa merupakan salah satu alternatif pengaturan keadaan lingkungan sebagai tempat tumbuh tanaman. Secara fisik mulsa mampu menjaga suhu tanah lebih stabil dan dapat mempertahankan kelembaban sekitar perakaran (Hamdani, 2008). Mulsa dapat bersumber dari bahan-bahan organik yang telah mati ataupun masih hidup yang sering disebut dengan biomulsa. Selain itu, juga terdapat mulsa yang berasal dari plastik. Bahan plastik yang saat ini sering digunakan adalah plastik transparan, plastik hitam, plastik perak, dan plastik hitam perak.

Tanaman penutup tanah (Legum cover crop) merupakan salah satu jenis biomulsa. Jenis tanaman penutup tanah yang sering digunakan adalah campuran dari Pueraria javanica, Calopogonium mucunoides, dan
Centrosema pubescens (Karyudi dan Siagian, 2006). Arachis pintoi atau yang sering disebut dengan kacang hias juga merupakan salah satu tanaman penutup tanah yang dapat tumbuh dengan baik di daerah tropika, baik di dataran rendah maupun dataran tinggi (Balittan, 2004). Fungsi tanaman penutup tanah sebagai biomulsa dapat mengurangi erosi permukaan tanah, merombak bahan organik dan cadangan unsur hara, menekan perkembangan gulma, menekan gangguan serangga, dan menjaga kelembapan tanah serta memperbaiki aerasi (Risza, 1995).

Baharrudin (2010) menambahkan bahwa upaya peningkatan produksi tanaman juga dapat dilakukan dengan cara menghilangkan atau mengurangi faktor-faktor yang dapat merugikan pertumbuhan tanaman. Gulma merupakan salah satu faktor yang dapat berperan sebagai pengganggu pertumbuhan tanaman. Keberadaan gulma dapat menyaingi tanaman utama dalam memperoleh nutrisi dalam tanah. Kehadiran gulma pada tanaman jagung manis merupakan penyebab rendahnya hasil jagung manis tersebut. Pengaruh gulma terhadap tanaman dapat terjadi secara langsung, yaitu dalam hal bersaing untuk mendapatkan unsur hara, air, cahaya, dan ruang tumbuh. Secara langsung sejumlah gulma merupakan inang dari hama dan penyakit. Gulma yang dibiarkan tumbuh pada tanaman jagung manis dapat menurunkan hasil 20\% - 80\% (Bilman, 2010). Tujuan penelitian ini adalah mengetahui pengaruh penggunaan tanaman penutup tanah A. pintoi sebagai biomulsa pada pertanaman jagung manis dibandingkan $C$. pubescens dan C. mucunoides.

\section{BAHAN DAN METODE}

Percobaan ini dilaksanakan di Kebun Percobaan Cikabayan Bawah, Kampus IPB Dramaga Bogor, mulai bulan FebruariSeptember 2013. Bahan yang digunakan pada penelitian ini adalah tiga macam tanaman penutup tanah yang terdiri atas stek batang $A$. pintoi, benih $C$. pubescens, $C$. mucunoides dan benih jagung manis varietas Bimmo. Pupuk yang digunakan berupa pupuk kandang kambing 20 ton ha- $\mathrm{h}^{-1}$, kapur 1 ton $\mathrm{ha}^{-1}$, dan NPK Mutiara. Bahan-bahan lain adalah Decis yang berperan sebagai insektisida, Rooton-F sebagai hormon pemicu pertumbuhan akar, serta furadan 3G untuk mencegah dari 
serangan serangga tanah saat penanaman benih jagung manis.

Percobaan dilakukan dengan menggunakan rancangan kelompok lengkap teracak (RKLT) satu faktor, yaitu dengan perlakuan perbedaan jenis mulsa berupa B0 = Vegetasi alami tanpa penyiangan, $\mathrm{B} 1=$ Kontrol (vegetasi alami dengan penyiangan), B2 = Mulsa Plastik Hitam Perak (MPHP), B3 = Biomulsa Arachis pintoi, $\mathrm{B} 4$ = Biomulsa Centrosema pubescens, serta B5 = Biomulsa Calopogonium mucunoides. Setiap perlakuan diulang sebanyak tiga kali sehingga terdapat 18 satuan percobaan. Satu satuan percobaan ialah petak dengan ukuran 5 $\mathrm{m}$ x $4 \mathrm{~m}$. Uji $\mathrm{F}$ digunakan untuk menganalisis pengaruh perlakuan. Bila perlakuan berpengaruh nyata diuji lanjut menggunakan uji Duncan Multiple Range Test (DMRT) pada taraf 5\%. Pengujian dilakukan dengan menggunakan aplikasi SAS.

Pelaksanaan penelitian meliputi pengolahan lahan dengan menggunakan traktor dan bajak. Setelah diolah, lahan dibuat petakan dengan ukuran $5 \mathrm{~m}$ x $4 \mathrm{~m}$ dengan jarak antar bedengan $50 \mathrm{~cm}$ dan tinggi bedengan $10 \mathrm{~cm}$. Petakan lahan kemudian diberi aplikasi pupuk kandang kambing 20 ton $\mathrm{ha}^{-1}$ dan kapur 1 ton $\mathrm{ha}^{-1}$. Lahan dibiarkan dua minggu sebelum ditanami tanaman penutup tanah. Bahan tanam tanaman penutup tanah $A$. pintoi berupa stek batang dengan panjang 4-5 buku setiap stek. Setelah dipotong-potong dengan ukuran tersebut kemudian stek direndam dalam larutan rooton-F dengan konsentrasi $1 \mathrm{~g} \mathrm{l}^{-1}$ air selama satu malam sebelum ditanam. Bahan tanam tanaman penutup tanah $C$. pubescens dan $C$. mucunoides yang digunakan berupa benih. Ketiga tanaman penutup tanah ditanam secara bersama-sama pada masing-masing petakan dengan jarak tanam yang digunakan adalah $10 \mathrm{~cm} \times 10 \mathrm{~cm}$.

Penanaman benih jagung manis dilakukan setelah penutupan tanaman penutup tanah mencapai $80 \%$. Benih jagung manis ditanam dengan cara membuat alur tanam di setiap petak yang berselang dengan tanaman penutup tanah. Lebar alur tanam yang dibuat seluas $50 \mathrm{~cm}$ di sepanjang petakan. Pemberian perlakuan mulsa plastik hitam perak dilakukan 3 hari sebelum penanaman benih jagung manis dengan membuat lubang berdiameter $10 \mathrm{~cm}$. Benih jagung manis ditanam pada lubang tanam dengan jarak tanam $80 \mathrm{~cm} \mathrm{x} 40 \mathrm{~cm}$ pada masing-masing petakan.
Kegiatan pemeliharaan yang dilakukan setelah penanaman tanaman penutup tanah hingga penanaman benih jagung manis meliputi penyiraman, pemupukan, penyiangan gulma, pengendalian hama dan penyakit, serta pembumbunan pada tanaman jagung manis yang dilakukan bersamaan dengan penyiangan gulma. Penyiangan gulma dilakukan secara manual sesuai dengan kebutuhan. Pemupukan dilakukan dua kali yaitu pada awal penanaman benih jagung manis dan saat tanaman jagung manis berumur 4 minggu setelah tanam (MST). Pemupukan dilakukan dengan cara menaburkan pupuk NPK ke dalam lubang yang telah dibuat di samping lubang tanam jagung manis dengan dosis $65.7 \mathrm{~g}$ tanaman $^{-1}$. Penyemprotan pestisida dilakukan satu kali saat tanaman jagung manis berumur 5 MST.

Pengamatan dilakukan terhadap tanaman contoh yang dipilih secara acak disetiap petakan. Peubah yang diamati adalah pada fase vegetatif meliputi tinggi tanaman $(\mathrm{cm})$, jumlah daun (helai), diameter batang (mm), lingkar batang $(\mathrm{cm})$, dan saat muncul bunga jantan/ tassel dengan satuan hari setelah tanam (HST). Saat fase generatif, peubah yang diamati meliputi jumlah tongkol tanaman ${ }^{-1}$ (tongkol), panjang tongkol $(\mathrm{cm})$, lingkar tongkol $(\mathrm{cm})$, dan jumlah baris biji tongkol ${ }^{-1}$ (baris). Komponen produksi jagung manis yang diamati meliputi bobot jagung dengan klobot (g), bobot jagung tanpa klobot (g), bobot brangkasan basah $(\mathrm{g})$, dan bobot brangkasan kering (g). Pergeseran dan perubahan jenis gulma akibat perlakuan diamati berdasarkan analisis vegetasi yang dilakukan di setiap petak percobaan.

\section{HASIL DAN PEMBAHASAN}

\section{Kondisi Umum}

Hasil analisis tanah yang dilakukan di Laboratorium Departemen Ilmu Tanah dan Sumberdaya Lahan menunjukkan bahwa kondisi awal tanah penelitian mengandung $\mathrm{pH}(4.8)$, C-organik (1.6\%), N-Total (0.14\%), $\mathrm{P}_{2} \mathrm{O}_{5}$ Bray $(62.40 \mathrm{ppm})$, dan $\mathrm{K}_{2} \mathrm{O}$ (94.53 ppm). Menurut Alloway (1995) hasil analisis tanah awal pada penelitian ini menunjukkan tanah bersifat masam serta kandungan $\mathrm{P}_{2} \mathrm{O}_{5}$ yang sangat tinggi yaitu $62.40 \mathrm{ppm}$, namun kandungan C-organik, N-Total, dan $\mathrm{K}$ termasuk 
rendah. Hal ini menunjukkan bahwa tanah masih membutuhkan lebih banyak bahan organik.

Pertumbuhan biomulsa $A$. pintoi mengalami kendala pada awal fase pertumbuhan seperti kekeringan akibat kekurangan air. Cuaca panas membuat stek batang A. pintoi mudah kering dan layu sehingga menghambat pertumbuhan akar dan tunas. Penanaman biomulsa $C$. pubescens dan $C$. mucunoides tidak mengalami kendala yang berarti saat awal penanaman. Pertumbuhan yang cepat pada kedua biomulsa ini membuat tanaman cepat merambat dan menutupi permukaan tanah.

Setelah penanaman jagung manis, pertumbuhan $C$. pubescens dan $C$. mucunoides yang merambat mengganggu tanaman jagung manis karena melilit batang jagung. Cara mengendalikannya yaitu dengan memangkas secara manual pada $C$. pubescens dan $C$. mucunoides yang melilit batang jagung manis. Kondisi seperti ini tidak dijumpai pada biomulsa A. pintoi. Hal ini merupakan salah satu keunggulan $A$. pintoi sebagai biomulsa dibandingkan C. pubescens dan C. mucunoides.

Pertumbuhan gulma terjadi pada semua petak perlakuan, termasuk pada perlakuan MPHP. Pertumbuhan gulma pada perlakuan MPHP terjadi di area lubang tanam. Secara umum setelah perlakuan biomulsa, pertumbuhan gulma lebih sedikit dibandingkan dengan sebelum perlakuan. Pertumbuhan dan perkembangan tanaman jagung manis secara umum lebih baik pada perlakuan MPHP dibandingkan dengan perlakuan lainnya.

Serangan hama dan penyakit merupakan salah satu faktor yang menghambat pada penelitian ini. Hama yang menyerang pertanaman jagung manis pada penelitian ini berupa belalang (Valanga sp.), ulat bulu (Spodoptera sp.), semut tanah, dan penggerek tongkol jagung (Helicoverpa armigera Hubner). Penyakit yang teridentifikasi menyerang tanaman jagung manis pada penelitian ini adalah penyakit bulai (Downy mildews). Intensitas serangan dari hama dan penyakit relatif rendah, sehingga masih dapat dikendalikan. Pengendalian pada hama dilakukan dengan menyemprotkan insektisida saat terjadi serangan hama. Pengendalian pada penyakit bulai dilakukan secara manual yaitu dengan mencabut dan menjauhkannya dari lahan pertanaman.

\section{Pengaruh Perlakuan Biomulsa terhadap Pergeseran Jenis Gulma}

Hasil analisis vegetasi yang dilakukan sebelum perlakuan dan setelah perlakuan biomulsa (4 MST setelah tanam jagung manis) disajikan pada Tabel 1. Data menunjukkan bahwa sebelum perlakuan, teridentifikasi 9 jenis gulma golongan rumput dan 5 jenis gulma golongan daun lebar, namun tidak ditemukan gulma dari golongan teki. Berdasarkan nilai jumlah dominasi (NJD), gulma golongan rumput (80.53\%) lebih dominan dibandingkan dengan gulma golongan daun lebar (19.47\%). Pengamatan yang dilakukan saat tanaman jagung manis berumur 4 MST menunjukkan bahwa perlakuan biomulsa mempengaruhi pergeseran jenis gulma.

Hasil pengamatan setelah perlakuan menunjukkan adanya pergeseran jenis gulma yang berbeda antar perlakuan. Perlakuan biomulsa A. pintoi mempengaruhi pergeseran jenis gulma golongan rumput dari 9 jenis menjadi 6 jenis, begitu juga dengan gulma golongan daun lebar mengalami pergeseran jenis. Berdasarkan NJD, gulma golongan daun lebar $(53.22 \%)$ pada perlakuan biomulsa $A$. pintoi lebih dominan dibandingkan gulma golongan rumput $(46.78 \%)$. Hal ini berbeda dengan perlakuan biomulsa $C$. pubescens dan C. mucunoides yang menghasilkan NJD gulma golongan rumput $(90.75 \%)$ dan $(89.75 \%)$ lebih dominan dibandingkan gulma golongan daun lebar $(9.25 \%)$ dan $(10.25 \%)$. Data tersebut menunjukkan bahwa ketiga jenis biomulsa ( $A$. pintoi, C. pubescens, dan C. mucunoides) kurang efektif menekan gulma golongan rumput. Meskipun demikian berdasarkan NJD, biomulsa A. pintoi relatif lebih efektif menekan gulma golongan rumput dibandingkan dengan $C$. pubescens, dan C. mucunoides.

Perlakuan biomulsa juga mempengaruhi munculnya jenis gulma baru, baik dari golongan rumput maupun golongan daun lebar. Terdapat jenis gulma baru yang muncul pada perlakuan A. pintoi yaitu A. compresus, C. dactylon, D. adcendens, dan I. cylindrica untuk gulma golongan rumput, sedangkan untuk jenis gulma golongan daun lebar terdapat B. latifolia, M. pudica, dan M. nudiflora (Tabel 1). Perlakuan vegetasi alami juga menurunkan jumlah jenis gulma rumput dari 9 jenis menjadi 3 jenis, dan gulma golongan daun lebar dari 5 jenis menjadi 4 jenis. Hasil 
NJD menunjukkan bahwa gulma golongan daun lebar (52.23\%) lebih dominan dibanding dengan gulma golongan rumput $(47.77 \%)$ pada perlakuan vegetasi alami. Selain itu, terdapat jenis gulma baru yang muncul pada perlakuan vegetasi alami yaitu I. cylindrica dan $R$. cochicinensis untuk gulma golongan rumput serta B. laevis, $C$. pubescens, dan $M$. pygra untuk gulma golongan daun lebar.

Beberapa penelitian melaporkan bahwa penggunaan $L C C$ kurang efektif untuk menekan gulma golongan rumput (Baharuddin, 2010;
Febrianto, 2012; Kartikawati et al., 2011). Penelitian Kartikawati et al. (2011) menyebutkan bahwa $C$. dactilon dan I. cylindrica dapat mendominasi pada pertumbuhan jagung yang diberi perlakuan tanaman penutup tanah Crotalaria juncea L. Hal ini karena gulma golongan rumput tersebut tumbuh tegak ke atas sehingga memperoleh faktor tumbuh yang cukup dan dapat mengimbangi pertumbuhan tanaman jagung dan tanaman penutup tanah $C$. juncea $\mathrm{L}$.

Tabel 1. Jenis gulma rumput yang tumbuh pada awal lahan percobaan sebelum olah tanah dan saat tanaman jagung manis berumur 4 MST

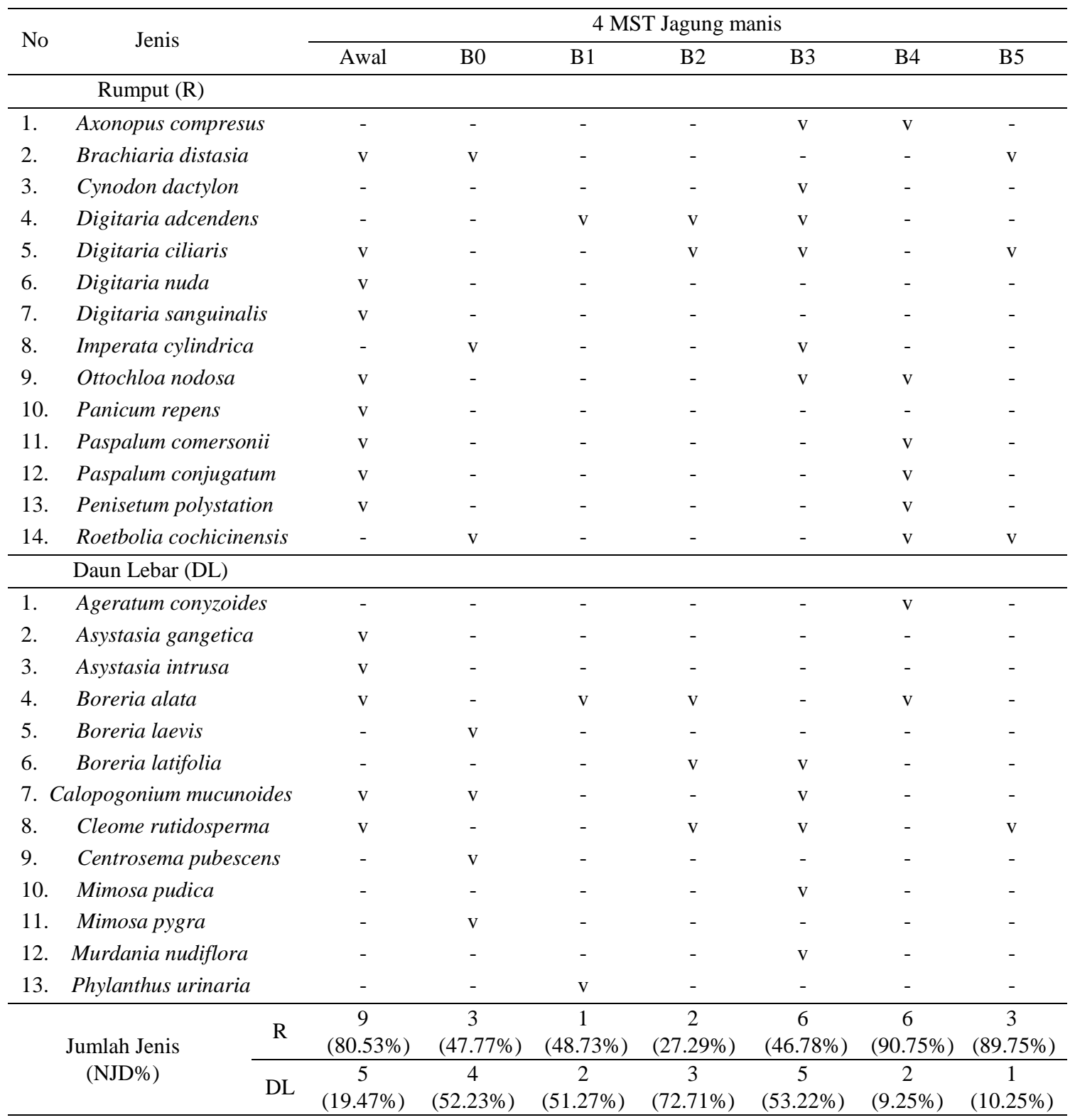

Keterangan : $\mathrm{B} 0=$ vegetasi alami, $\mathrm{B} 1=$ kontrol, B2 $=\mathrm{MPHP}, \mathrm{B} 3=A$. pintoi, $\mathrm{B} 4=C$. pubescens, $\mathrm{B} 5=C$. Mucunoides $\mathrm{R}=$ rumput-rumputan, $\mathrm{DL}=$ daun lebar, $\mathrm{NJD}=$ nilai jumlah dominasi. 
Hasil lain yang menarik adalah hasil pengamatan yang menunjukkan bahwa perlakuan biomulsa $A$. pintoi dapat menekan secara efektif pertumbuhan gulma golongan rumput $R$. cochicinensis, gulma penting yang keberadaannya dapat mendominasi area pertanaman. Berdasarkan Tabel 1, gulma $R$. cochicinensis dapat tumbuh pada perlakuan biomulsa $C$. pubescens dan $C$. mucunoides, namun tidak ditemukan pada perlakuan biomulsa $A$. pintoi. Penelitian Febrianto (2012) menyebutkan bahwa keberadaan gulma $R$. exaltata merupakan salah satu gulma yang mendominasi saat lahan belum dilakukan pengolahan. Saat awal penanaman A. pintoi, gulma yang mendominasi dalam penelitiannya adalah jenis daun lebar dan saat penutupan A. pintoi hampir $100 \%$ gulma yang mendominasi adalah Axonopus compresus yang merupakan gulma golongan rumput. Gulma $R$. exaltata tidak teridentifikasi setelah aplikasi perlakuan biomulsa A. pintoi.

\section{Pengaruh Perlakuan Biomulsa terhadap Pertumbuhan dan Produksi Jagung Manis}

Hasil analisis ragam menunjukkan perbedaan jenis mulsa berpengaruh nyata terhadap semua peubah pengamatan kecuali pada panjang tongkol dan lingkar tongkol menunjukkan pengaruh tidak nyata (Tabel 2).

\section{Pertumbuhan Vegetatif Tanaman Jagung Manis}

Berdasarkan hasil pada Tabel 3, tinggi tanaman pada perlakuan biomulsa $A$. pintoi $(96.19 \mathrm{~cm})$ lebih rendah dan berbeda nyata dengan perlakuan MPHP $(171.40 \mathrm{~cm})$, tetapi tidak berbeda nyata dengan perlakuan biomulsa $C$. pubescens $(85.75 \mathrm{~cm})$ dan $C$. mucunoides $(96.52 \mathrm{~cm})$ serta perlakuan lainnya. Perlakuan biomulsa A. pintoi memiliki kecenderungan meningkatkan tinggi tanaman jagung manis dibandingkan perlakuan biomulsa $C$. pubescens. Hasil percobaan ini berbeda dengan percobaan Subaedah et al. (2011) yang menyatakan bahwa penanaman jagung dengan perlakuan tanaman penutup tanah (TPT) $C$. pubescens menghasilkan tinggi tanaman yang lebih tinggi dibandingkan perlakuan tanaman penutup tanah (TPT) C. mucunoides. Hal ini terjadi karena pertumbuhan biomulsa $C$. pubescens pada percobaan ini lebih cepat bila dibandingkan biomulsa $C$. mucunoides, sehingga biomulsa $C$. pubescens melilit batang jagung manis dan menghambat pertumbuhan.

Jumlah daun pada perlakuan biomulsa A. pintoi (6.9) tidak berbeda nyata dengan perlakuan biomulsa $C$. pubescens (6.2), $C$. mucunoides (7.4) dan perlakuan vegetasi alami (7.0). Perlakuan biomulsa A. pintoi menghasilkan jumlah daun yang lebih sedikit (6.9) serta berbeda nyata dengan perlakuan kontrol (8.4) dan perlakuan MPHP (9.8). Jumlah daun terbanyak diperoleh pada perlakuan MPHP (Tabel 3). Perlakuan MPHP sebagai mulsa menghasilkan kelembaban yang tepat, sehingga mempengaruhi suhu tanah menjadi rendah. Menurut Mc Williams et al. (1999) suhu tanah yang rendah akan meningkatkan jumlah daun pada jagung manis.

Tabel 2. Rekapitulasi analisis ragam pengaruh perlakuan perbedaan jenis mulsa terhadap parameter pengamatan

\begin{tabular}{|c|c|c|}
\hline Karakter & F hitung & $\mathrm{KK}(\%)$ \\
\hline Tinggi tanaman $(\mathrm{cm})$ & $25.16 * *$ & 9.61 \\
\hline Jumlah daun (daun) & $10.88 * *$ & 8.91 \\
\hline Diameter batang $(\mathrm{mm})$ & $3.58 *$ & 19.31 \\
\hline Lingkar batang $(\mathrm{cm})$ & $11.49 * *$ & 11.09 \\
\hline Muncul bunga (HST) & $185.8 * *$ & 1.16 \\
\hline $\begin{array}{l}\text { Jumlah tongkol/tanaman } \\
\text { (tongkol) }\end{array}$ & $37.73 * *$ & 5.09 \\
\hline Panjang tongkol $(\mathrm{cm})$ & $5.34 \mathrm{tn}$ & 11.12 \\
\hline Lingkar tongkol (cm) & $2.57 \mathrm{tn}$ & 12.37 \\
\hline $\begin{array}{l}\text { Jumlah baris/tongkol } \\
\text { (baris) }\end{array}$ & $5.90 * *$ & 13.12 \\
\hline $\begin{array}{l}\text { Bobot jagung dengan } \\
\text { klobot }(\mathrm{g})\end{array}$ & $20.35 * *$ & 30.22 \\
\hline $\begin{array}{l}\text { Bobot jagung tanpa } \\
\text { klobot }(\mathrm{g})\end{array}$ & $21.89 * *$ & 25.05 \\
\hline $\begin{array}{l}\text { Bobot brangkasan basah } \\
\text { (g) }\end{array}$ & $17.51 * *$ & 25.25 \\
\hline $\begin{array}{l}\text { Bobot brangkasan kering } \\
(\mathrm{g})\end{array}$ & $12 * *$ & 31.62 \\
\hline
\end{tabular}


Tabel 3. Pengaruh perbedaan jenis biomulsa terhadap pertumbuhan vegetatif dan umur berbunga jagung manis

\begin{tabular}{lccccc}
\hline Perlakuan Biomulsa & $\begin{array}{c}\text { Tinggi } \\
\text { Tanaman } \\
(\mathrm{cm})^{\mathrm{x}}\end{array}$ & $\begin{array}{c}\text { Jumlah } \\
\text { Daun } \\
(\text { helai })^{\mathrm{x}}\end{array}$ & $\begin{array}{c}\text { Diameter } \\
\text { batang } \\
(\mathrm{mm})^{\mathrm{x}}\end{array}$ & $\begin{array}{c}\text { Lingkar } \\
\text { Batang } \\
(\mathrm{cm})^{\mathrm{x}}\end{array}$ & $\begin{array}{c}\text { Umur Berbunga } \\
(\text { HST })^{\mathrm{x}}\end{array}$ \\
$\begin{array}{l}\text { Tanpa penyiangan } \\
\text { (Vegetasi alami) }\end{array}$ & $102.54 \mathrm{bc}$ & $6.9 \mathrm{c}$ & $9.29 \mathrm{abc}$ & $4.07 \mathrm{bc}$ & $59 \mathrm{c}$ \\
$\begin{array}{l}\text { Penyiangan manual } \\
\text { (Kontrol) }\end{array}$ & $116.33 \mathrm{~b}$ & $8.4 \mathrm{~b}$ & $11.04 \mathrm{ab}$ & $4.56 \mathrm{~b}$ & $60 \mathrm{c}$ \\
MPHP & $171.40 \mathrm{a}$ & $9.8 \mathrm{a}$ & $12.65 \mathrm{a}$ & $6.41 \mathrm{a}$ & $51 \mathrm{~d}$ \\
A. pintoi & $96.19 \mathrm{bc}$ & $6.9 \mathrm{c}$ & $8.72 \mathrm{bc}$ & $4.27 \mathrm{bc}$ & $64 \mathrm{~b}$ \\
C. pubescens & $85.75 \mathrm{c}$ & $6.2 \mathrm{c}$ & $6.64 \mathrm{c}$ & $3.58 \mathrm{c}$ & $66 \mathrm{a}$ \\
C. mucunoides & $96.52 \mathrm{bc}$ & $7.3 \mathrm{bc}$ & $10.03 \mathrm{abc}$ & $4.21 \mathrm{bc}$ & $65 \mathrm{ab}$ \\
\hline
\end{tabular}

Keterangan: ${ }^{x}$ Angka-angka yang diikuti huruf yang sama tidak berbeda nyata berdasarkan uji DMRT pada taraf uji $5 \%$. MPHP = mulsa plastik hitam perak

Rata-rata diameter batang yang dihasilkan pada perlakuan biomulsa $A$. pintoi $(8.72 \mathrm{~mm})$ lebih rendah dan berbeda nyata dengan perlakuan MPHP (12.65 mm), sedangkan pada perlakuan biomulsa C. mucunoides $(10.03 \mathrm{~mm})$ lebih rendah namun tidak berbeda nyata dengan perlakuan MPHP. Begitu juga pada peubah lingkar batang, perlakuan biomulsa A. pintoi $(4.27 \mathrm{~cm})$ lebih rendah dan berbeda nyata dengan perlakuan MPHP $(6.41 \mathrm{~cm})$, namun tidak berbeda nyata dengan perlakuan lainnya.

Umur berbunga pada perlakuan $A$. pintoi (64 HST) lebih cepat dan berbeda nyata dengan perlakuan biomulsa $C$. pubescens $(66$ HST), namun lebih lambat dan berbeda nyata dengan perlakuan MPHP (51 HST). Umur berbunga pada perlakuan MPHP merupakan umur yang paling cepat dibandingkan dengan perlakuan lainnya (Tabel 2). Hal ini sejalan dengan penelitian Subekti et al. (2010), yang me-nyatakan bahwa fase tasseling biasa terjadi saat umur tanaman jagung manis berkisar 4552 HST.

\section{Komponen Hasil Produksi Jagung Manis}

Komponen hasil produksi jagung manis sangat dipengaruhi oleh fase pertumbuhan (vegetatif). Pertumbuhan vegetatif yang baik pada jagung manis mempengaruhi pertumbuhan generatif yang dihasilkan juga baik (Marliah et al., 2010). Subekti et al. (2010) dalam penelitiannya menambahkan bahwa hasil dan bobot biomas jagung yang tinggi akan diperoleh jika pertumbuhan tanaman optimal. Rekapitulasi sidik ragam pada Tabel 1 menunjukkan penggunaan berbagi jenis mulsa berpengaruh nyata terhadap komponen jagung manis.

Berdasarkan Tabel 4, rata-rata jumlah tongkol untuk setiap tanaman jagung manis pada perlakuan biomulsa A. pintoi adalah satu tongkol. Hal ini sama dan tidak berbeda nyata dengan perlakuan lainnya, namun lebih rendah dan berbeda nyata dengan perlakuan MPHP (1.5 buah). Panjang tongkol pada perlakuan biomulsa $A$. pintoi $(13.40 \mathrm{~cm})$ lebih rendah namun tidak berbeda nyata dengan kontrol $(14.76 \mathrm{~cm})$, sedangkan jika dibandingkan dengan perlakuan MPHP $(17.15 \mathrm{~cm})$, panjang tegak pada perlakuan biomulsa A. pintoi lebih rendah dan berbeda nyata.

Peubah lingkar tongkol pada perlakuan biomulsa $A$. pintoi tidak berbeda nyata dengan perlakuan lainnya (Tabel 4), sedangkan lingkar batang pada perlakuan biomulsa $C$. pubescens $(9.94 \mathrm{~cm})$ dan C. mucunoides $(9.95$ $\mathrm{cm})$ lebih rendah dan berbeda nyata dengan perlakuan MPHP $(12.98 \mathrm{~cm})$. Berdasarkan Tabel 4, rata-rata jumlah baris setiap tongkol pada perlakuan $A$. pintoi (9.6 baris) lebih sedikit dan berbeda nyata dengan kontrol (12.3 baris) dan perlakuan MPHP (13.5 baris), namun tidak berbeda nyata dengan perlakuan lainnya. 


\section{J. Hort. Indonesia 5(1):1-9. April 2014.}

Tabel 4. Pengaruh perlakuan biomulsa pada komponen hasil jagung manis

\begin{tabular}{|c|c|c|c|c|}
\hline Perlakuan & $\begin{array}{c}\text { Jumlah Tongkol/ } \\
\text { Tanaman } \\
\text { (tongkol) }^{\mathrm{x}}\end{array}$ & $\begin{array}{l}\text { Panjang } \\
\text { Tongkol } \\
(\mathrm{cm})^{\mathrm{x}}\end{array}$ & $\begin{array}{c}\text { Lingkar } \\
\text { Tongkol }(\mathrm{cm}) \\
\mathrm{x}\end{array}$ & 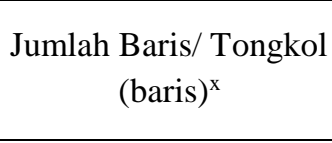 \\
\hline VegetasiAlami & $1.0 \mathrm{~b}$ & $14.17 b c$ & 11.78ab & $12.1 \mathrm{ab}$ \\
\hline Kontrol & $1.0 \mathrm{~b}$ & $14.76 \mathrm{ab}$ & $12.44 \mathrm{ab}$ & $12.3 \mathrm{a}$ \\
\hline MPHP & $1.5 \mathrm{a}$ & $17.15 \mathrm{a}$ & $12.98 \mathrm{a}$ & $13.5 \mathrm{a}$ \\
\hline A. pintoi & $1.0 \mathrm{~b}$ & $13.40 \mathrm{bc}$ & $10.73 \mathrm{ab}$ & $9.6 b c$ \\
\hline C. pubescens & $1.0 \mathrm{~b}$ & $12.09 \mathrm{bc}$ & $9.94 b$ & $8.5 c$ \\
\hline C. mucunoides & $1.0 \mathrm{~b}$ & $11.41 \mathrm{c}$ & $9.95 b$ & $9.3 \mathrm{c}$ \\
\hline
\end{tabular}

Keterangan: ${ }^{\mathrm{x}}$ Angka-angka yang diikuti huruf yang sama tidak berbeda nyata berdasarkan uji DMRT pada taraf uji 5\%

Tabel 5. Pengaruh perlakuan biomulsa terhadap rata-rata hasil jagung manis

\begin{tabular}{lcccc}
\hline Perlakuan & $\begin{array}{c}\text { Bobot Jagung } \\
\text { Berkelobot }(\mathrm{g}) \\
\mathrm{x}\end{array}$ & $\begin{array}{c}\text { Bobot Jagung } \\
\text { Tanpa Klobot } \\
(\mathrm{g})^{\mathrm{x}}\end{array}$ & $\begin{array}{c}\text { Brangkasan Basah } \\
(\text { per tanaman } \\
\left.\text { contoh }(\mathrm{g})^{\mathrm{x}}\right)\end{array}$ & $\begin{array}{c}\text { Brangkasan kering } \\
(\text { per tanaman contoh } \\
\left.(\mathrm{g})^{\mathrm{x}}\right)\end{array}$ \\
\hline Vegetasi Alami & $90 \mathrm{~b}$ & $66 \mathrm{bc}$ & $104 \mathrm{c}$ & $21.84 \mathrm{c}$ \\
Kontrol & $133 \mathrm{~b}$ & $96 \mathrm{~b}$ & $184 \mathrm{~b}$ & $59.39 \mathrm{~b}$ \\
MPHP & $338 \mathrm{a}$ & $189 \mathrm{a}$ & $350 \mathrm{a}$ & $104.27 \mathrm{a}$ \\
A. pintoi & $85 \mathrm{~b}$ & $54 \mathrm{c}$ & $108 \mathrm{bc}$ & $37.51 \mathrm{bc}$ \\
C. pubescens & $67 \mathrm{~b}$ & $43 \mathrm{c}$ & $107 \mathrm{bc}$ & $33.91 \mathrm{bc}$ \\
C. mисunoides & $69 \mathrm{~b}$ & $45 \mathrm{c}$ & $109 \mathrm{bc}$ & $30.59 \mathrm{bc}$ \\
\hline
\end{tabular}

Keterangan: ${ }^{x}$ Angka-angka yang diikuti huruf yang sama tidak berbeda nyata berdasarkan uji DMRT pada taraf uji $5 \%$.

Peubah bobot jagung berkelobot pada perlakuan biomulsa A. pintoi (85 g) lebih rendah dan berbeda nyata dengan perlakuan MPHP (338 g), namun tidak berbeda nyata dengan perlakuan lainnya (Tabel 5). Rata-rata bobot jagung tanpa klobot setiap tanaman pada perlakuan biomulsa $A$. pintoi (54 g) lebih rendah dan berbeda nyata dengan kontrol (96 g) dan perlakuan MPHP (189 g).

Rata-rata bobot brangkasan basah dan brangkasan kering jagung manis dapat dilihat pada Tabel 5 Bobot brangkasan basah pada perlakuan biomulsa A. pintoi (108 g) lebih rendah dan berbeda nyata dengan perlakuan MPHP (350 g), namun tidak berbeda nyata dengan perlakuan lainnya (Tabel 5). Begitu juga bobot brangkasan kering, pada perlakuan A. pintoi $(37.51 \mathrm{~g})$ lebih rendah dan berbeda nyata dengan perlakuan MPHP (104.27 g). Bobot brangkasan kering pada perlakuan MPHP paling tinggi dan berbeda nyata dengan perlakuan lainnya.

\section{KESIMPULAN}

Penggunaan biomulsa mempengaruhi pergeseran jenis gulma. Biomulsa A. pintoi lebih baik dalam menekan gulma golongan rumput dibandingkan dengan $C$. pubescens dan $C$. mucunoides. Pertumbuhan komponen hasil dan hasil jagung manis tidak berbeda nyata antara perlakuan biomulsa $A$. pintoi, $C$. pubescens, dan $C$. mucunoides. Perlakuan terbaik dalam mendukung komponen hasil dan hasil ialah mulsa plastic hitam pekat.

\section{DAFTAR PUSTAKA}

Baharuddin, R. 2010. Penggunaan kacang hias (Arachis pintoi) sebagai biomulsa pada budidaya tomat (Lycopersicon esculentum M.) skripsi. Institut Pertanian Bogor. Bogor.

Balittan. 2004. Kacang hias (Arachis pintoi) pada usaha tani lahan. http://balittanah. litbang.deptan.go.id.html.[14 November 2012]. 
Bilman, W.S. 2010. Analisis pertumbuhan tanaman jagung manis (Zea mays saccharata), pergeseran komposisi gulma pada beberapa jarak tanam jagung dan beberapa frekuensi pengolahan tanah. J. Ilmu-Ilmu Pertanian Indonesia. 3(1): 25-30.

Febrianto, Y. 2012. Pengaruh jarak tanam dan jenis stek terhadap kecepatan penutupan Arachis pintoi Krap. \& Greg. sebagai biomulsa pada pertanaman tomat (Lycopersicon esculentum M.) skripsi. Institut Pertanian Bogor. Bogor.

Hamdani, J.S. 2008. Pengaruh jenis mulsa terhadap pertumbuhan dan hasil tiga kultivar kentang (Solanum tuberosum L.) yang ditanam di dataran medium. J. Agron. Indonesia. 37(1): 14-19.

Kartikawati, L.D., S. Titin, T.S. Husni. 2011. Pengaruh aplikasi pupuk kandang dan tanaman sela (Crotalaria juncea L) pada gulma dan pertanaman jagung (Zea mays L) skripsi. Universitas Brawijaya. Malang.

Marliah, A., Jumini, Jamilah. 2010. Pengaruh jarak tanam antar barisan pada sistem tumpangsari beberapa varietas jagung manis dengan kacang merah terhadap pertumbuhan dan hasil. Bul. Agrista. 14(1): 30-38.

Mayadewi, N.N.A. 2007. Pengaruh jenis pupuk kandang dan jarak tanam terhadap pertumbuhan gulma dan hasil jagung manis. Bul. Agritrop. 26(4): 153-159.
Mc Williams, D.A., D.R. Benglund, G.J. Endres. 1999. Corn growth and management quick guide. www.ag. ndsu.edu/pubs/plantsci/rowcrops/a1173/a 1173.pdf. [diunduh 23 November 2013].

Rahayu, S. 2011. Tanaman penutup tanah [Internet]. Tersedia pada: http://www. worldagroforestry.org/index.php?id=20 [12 Maret 2012].

Risza, R. 1995. Budidaya Kelapa Sawit. AAK. Kanisisus. Yogyakarta.

Karyudi, Siagian N. 2006. Peluang dan kendala dalam pengusahaan tanaman penutup tanah di perkebunan karet. hlm 25-33. Prosiding Lokakarya Nasional Tanaman Pakan Ternak. Pusat Penelitian dan Pengembangan Peternakan. Bogor.

Sintia, M. 2011. Pengaruh beberapa dosis kompos jerami padi dan pupuk nitrogen terhadap pertumbuhan dan hasil jagung manis (Zea mays saccharata Sturt.). J. Tanaman Pangan. 1-7.

Subaedah, S., N.A. Jalal, Suriyanti, B. Ibrahim. 2011. Perbaikan hasil tanaman jagung di lahan kering dengan pengelolaan tanaman penutup tanah. J. Agrivigor. 10(2): 122-129.

Subekti, N.A., Syarifuddin, R. Efendi, S. Sunarti. 2007. Morfologi Tanaman dan Fase Pertumbuhan Jagung [internet]. Tersedia pada: www.pustaka.litbang. deptan.go.id/bbps/lengkab/bpp10232.pdf. 2007. [16 November 2013]. 